\title{
Peningkatan Kemampuan Berpikir Kreatif Siswa Melalui Pendekatan Matematika Realistik
}

\author{
Rama Nida Siregar ${ }^{1 *}$, Abdul Mujib ${ }^{2 *}$, Hasratuddin $^{3}$, Ida Karnasih ${ }^{4}$ \\ 1,2,4 Universitas Muslim Nusantara Al- Wasliyah Medan. \\ ${ }^{3}$ Universitas Negeri Medan.
}

* Corresponding Author. E-mail: ramanidasiregar@gmail.com \& mujib_umnaw@yahoo.co.id

Receive: 01/02/2020

Accepted:20/02/2020

Published: 1/03/2020

\begin{abstract}
Abstrak
Penelitian ini dilatarbelakangi oleh masalah, masih rendahnya tingkat kemampuan berpikir kreatif siswa. Salah satu alternatif pembelajaran yang dapat diterapkan untuk meningkatkan kemampuan berpikir kreatif siswa adalah pendekatan matematika realistik. Tujuan penelitian ini adalah untuk mengetahui peningkatan kemampuan berpikir kreatif siswa dengan pendekatan matematika realistik dalam pembelajaran matematika, serta mengetahui respon siswa terhadap pembelajaran matematika dengan penggunaan pendekatan matematika realistik. Metode yang digunakan dalam penelitian ini adalah metode kuasi eksperimen, dengan desain penelitian Control group pretes-postes. Penelitian dilaksanakan di SMP Swasta Al-Ulum Medan. Populasi dalam penelitian ini adalah seluruh siswa kelas VII SMP Swasta Al-Ulum Medan. Sampel dalam penelitian ini adalah siswa kelas VII 3 sebagai kelas eksperimen dan kelas VII 5 sebagai kelas kontrol yang dipilih secara random kelas. Kelas eksperimen diberikan perlakuan dengan pendekatan matematika realistik dan kelas kontrol diberikan perlakuan pembelajaran konvensional. Adapun instrumen yang digunakan adalah berupa tes berpikir kreatif untuk melihat kemampuan berpikir kreatif yang telah diujicobakan dan angket untuk melihat respon siswa. Dalam penelitian ini diperoleh data kualitatif dan data kuantitatif. Data kuantitatif dianalisis menggunakan analisis statistik uji $t$ untuk melihat peningkatan kemampuan berpikir kreatif siswa dengan pendekatan matematika realistik dalam pembelajaran matematika. Data kualitatif dianalisis menggunakan skala sikap Likert untuk mengetahui respon siswa terhadap pembelajaran matematika dengan penggunaan pendekatan matematika realistik. Berdasarkan analisis hasil tes berpikir kreatif diperoleh kesimpulan yaitu terdapat peningkatan kemampuan berpikir kreatif siswa pendekatan matematika realistik.
\end{abstract}

Kata Kunci: pendekatan matematika realistik, dan berpikir kreatif siswa

\section{Increasing Students' Creative Thinking Abilities Through a Realistic Mathematical Education}

\section{Abstract}

This research is motivated by problems, the low level of students' creative thinking abilities. One alternative learning that can be applied to improve students' creative thinking abilities is a realistic mathematical education. The purpose of this study was to determine the increase in students 'creative thinking abilities with a realistic mathematical education in mathematics learning, and to determine students' responses to mathematics learning by using a realistic mathematics approach. The method used in this study is a quasi-experimental method, with the control group pretest-posttest research design. The study was conducted of Junior High School Student at Al-Ulum Medan. The population in this study were all grade VII Junior High School Student at Al-Ulum Medan. The sample in this study 
were students of class VII 3 as an experimental class and class VII 5 as a control class chosen randomly by class. The experimental class was given treatment with a realistic mathematical approach and the control class was given conventional learning treatment. The instrument used is a creative thinking test to see the ability of creative thinking that has been tested and a questionnaire to see student responses. In this study obtained qualitative data and quantitative data. Quantitative data were analyzed using $t$-test statistical analysis to see an increase in students' creative thinking abilities with a realistic mathematical education in learning mathematics. Qualitative data were analyzed using a Likert attitude scale to determine students' responses to mathematics learning by using realistic mathematics approaches. Based on the analysis of the results of the creative thinking test the conclusion is that there is an increase in the students' creative thinking abilities in a realistic mathematical approach.

Keywords: realistic mathematics education, and students' creative thinking

\section{Pendahuluan}

Kemajuan ilmu pengetahuan dan teknologi menuntut seseorang untuk dapat menguasai informasi dan pengetahuan. Kemampuan-kemampuan tersebut juga membutuhkan pemikiran yang kritis, sistematis, logis, dan kreatif. Oleh karena itu diperlukan suatu kemampuan memperoleh, memilih dan mengolah informasi melalui kemampuan berfikir kritis, sistematis, logis dan kreatif. Salah satu program pendidikan yang dapat mengembangkan kemampuan berfikir kritis, sistematis, logis, dan kreatif adalah matematika (Siregar, 2019). Matematika terbentuk dari pengalaman manusia dalam dunianya secara empiris (Mujib, 2018), kemudian pengalaman itu diproses di dalam dunia rasio, diolah secara analisis dengan penalaran di dalam struktur kognitif sehingga sampai terbentuk konsep-konsep matematika supaya konsep-konsep matematika yang terbentuk itu mudah dipahami oleh orang lain dan dapat dimanipulasi secara tepat, maka digunakan bahasa matematika atau notasi matematika yang bernilai global (universal). Konsep matematika didapat karena proses berpikir, karena itu logika adalah dasar terbentuknya matematika (Mujib, 2018).

Van de walle (Siregar, 2019) menambahkan hal yang paling mendasar dalam matematika adalah matematika dapat dipahami dan masuk akal artinya:

1. Setiap hari siswa harus mendapatkan pengalaman bahwa matematika masuk akal.
2. Para siswa harus percaya bahwa mereka mampu memahami matematika.

3. Para guru harus menghentikan cara mengajar dengan memberitahu segalanya kepada siswa dan harus mulai memberi kesempatan kepada siswa untuk memahami matematika yang sedang mereka pelajari.

4. Akhirnya para guru harus percaya terhadap kemampuan siswa.

Sehubungan dengan hal itu maka proses pembelajaran matematika di kelas sudah seharusnya dilakukan perubahan. Konsep matematika harus dibangun dengan pemahaman siswa itu sendiri. Hal yang harus dilakukan guru adalah bagaimana mendorong siswa untuk berfikir, bertanya, memecahkan masalah, mengemukakan ide, mendiskusikan ide bahkan menemukan sesuatu yang baru. Sebagaimana dikemukakan Van de Walle (Siregar, 2019) yang mengatakan bahwa "guru harus mengubah pendekatan pengajarannya dari pengajaran berpusat pada guru menjadi pengajaran berpusat pada siswa". Artinya guru perlu mengubah kelas dari sekedar kumpulan siswa menjadi komunitas matematika, menjadikan logika dan bukti matematika sebagai pembenaran dan menjauhkan otoritas guru untuk menuntaskan kebenaran. Mementingkan pemahaman daripada hanya mengingat prosedur, mementingkan membuat dugaan, penemuan dan pemecahan soal dan menjauhkan dari tekanan pada penemuan jawaban secara mekanis. Mengaitkan matematika, ide-ide dan aplikasinya dan tidak memperlakukan matematika sebagai 
kumpulan konsep dan prosedur yang terasingkan.

Kemampuan berpikir kreatif adalah kemampuan menganalisis sesuatu berdasarkan data atau informasi yang tersedia namun juga melahirkan konsepkonsep baru yang jauh lebih sempurna dan menentukan alternatif-alternatif dengan berbagai ide yang dapat digunakan untuk memecahkan permasalahannya. Dalam berpikir kreatif, seseorang akan melalui tahapan mensintesis ide-ide, juga melahirkan konsep-konsep baru yang jauh lebih sempurna dalam merencanakan penggunaan ide-ide, dan mengimplementasikan ide-ide tersebut sehingga menghasilkan sesuatu yang baru dan lebih sempurna. Menurut Alvino (Budiarto, 2013) menyatakan bahwa berpikir kreatif adalah berbagai cara untuk melihat atau melakukan sesuatu yang dikarakteristik ke dalam empat komponen, yaitu 1) Kelancaran (membuat berbagai ide; 2) Kelenturan (keahlian memandang ke depan dengan mudah); 3) keaslian (menyusun suatu yang baru); 4) Elaborasi (membangun sesuatu dari ide-ide lainnya).

kenyataannya kemampuan berfikir kreatif siswa masih tergolong rendah. Kenyataan yang kurang memuaskan itu, disebabkan oleh banyak faktor, diantaranya pembelajaran masih berpusat pada guru yang kurang kreatif dan inovatif dalam pembelajaran di kelas. Hal itu terlihat dari kurang bermaknanya kegiatan pembelajaran yang dilakukan oleh guru. Akibatnya, guru biasanya langsung mengajarkan dengan cara buku (teks book oriented).

(Saragih, 2017) mengungkapkan yang artinya sebagian besar guru-guru banyak mengaplikasikan pembelajaran berpusat pada guru. Guru memulai pembelajaran dengan memberikan penjelasan atau contoh-contoh materi tanpa menggabungkan dengan lingkungan sekitar (konteks kehidupan nyata), kemudian dilanjutkan dengan memberikan tugas. Interaksi antara siswa dan guru jarang terjadi. Guru mendominasi proses belajar yang berdampak pada sedikitnya kesempatan siswa untuk mengembangkan kemampuannya melalui proses belajar yang didesain untuk menemukan konsep. Hal ini menunjukkan guru-guru tidak memiliki pengetahuan tentang konsep belajar berdasarkan paradigma baru dengan siswa sebagai pusat dalam proses pembelajaran.

Pada kenyataannya siswa tidak banyak terlibat dalam mengkontruksi pengetahuan yang dimilikinya, hanya menerima informasi yang disampaikan searah dari guru. Fenomena ini sebagai pemicu melemahnya berfikir kreatif matematis siswa, yang akhirnya akan berimbas pada kemampuan berfikir kreatif matematis siswa menjadi rendah. Hal ini menjadi tantangan bagi guru untuk terus menerus menciptakan suasana belajar yang lebih bermutu.

Lebih lanjut mata pelajaran matematika masih dianggap mata pelajaran yang sulit, abstrak, dan tidak menyenangkan oleh banyak siswa. Hal ini ditunjukan dengan adanya fenomena siswa yang menganggap matematika banyak sekali rumus yang harus dihafalkan. Selain itu guru terlalu monoton dan serius sekali dalam menjelaskan materi matematika sehingga membuat matematika adalah pelajaran paling membosankan. Seorang guru cenderung untuk menjelaskan konsep matematika yang abstrak berdasarkan cara buku. Cara mengajar seorang guru dengan cara buku, merupakan salah satu faktor yang menyebabkan materi matematika itu sulit di pahami oleh siswa. Fungsi seorang guru adalah membantu siswa untuk memahami konsep matematika yang ada di buku paket. Jika pada kenyataanya guru yang bersangkutan menjelaskan konsep yang ada berdasarkan bahasa buku tanpa menggunakan kemampuan mereka untuk membuat penyampaian yang lebih ringan, tentunya hal ini tidak membantu siswa memahami konsep, tetapi membantu siswa membaca buku. Kalau kasusnya sudah seperti ini, tetap saja akan membuat siswa berada pada kebingungan mereka dan pada akhirnya jatuh pada pernyataan bahwa matematika itu sulit. Padahal banyak sekali 
hal yang bisa dilakukan oleh guru agar pelajaran matematika lebih menarik minat dari siswa. Misalkan saja melalui berbagai pendekatan pembelajaran yaitu pendekatan matematika realistik.

Pendekatan realistik dapat mendorong siswa untuk memahami materi pelajaran secara lebih nyata atau tidak abstrak, karena guru menggunakan contoh atau alat peraga benda yang berada di sekitarnya sehingga mudah dipahami. Hal ini juga dapat merangsang minat belajar siswa akan konsep matematika yang terkesan monoton dan abstrak karena pendekatan matematika realistik sangat erat dengan masalahmasalah yang terjadi pada kehidupan sehari-hari. Sehingga dapat menjadikan pembelajaran matematika lebih nyata atau tidak terkesan abstrak. Dalam hal ini pendekatan matematika realistik membantu sebagian besar siswa memahami materi yang telah diberikan oleh guru secara menyenangkan dan tidak terkesan abstrak.

Menurut (Hariyati, 2013), Pendekatan Realistik adalah suatu pendekatan pembelajaran yang diawali dengan masalah kontekstual untuk mengarahkan siswa dalam memahami suatu konsep matematika. Dikatakan pula Pendekatan Realistik merupakan pendekatan pembelajaran matematika yang berorienktasi pada kehidupan sehari-hari (Siregar, 2019). Konsep Pendekatan Realistik menjelaskan bahwa pada pembelajaran matematika, siswa harus aktif dan pembangunan ide harus dilakukan oleh siswa sendiri, guru hanya sebagai fasilitator (Siregar, 2019).

Tujuan dari penelitian ini yaitu untuk mengetahui apakah terdapat peningkatan kemampuan berpikir kreatif siswa dengan pendekatan matematika realistik.

\section{Metode}

Metode eksperimen dalam penelitian ini menggunakan jenis desain penelitian dengan metode pretest-posttest control group design. Dalam desain ini, Sugiyono menyatakan "bahwa terdapat dua kelompok yang dipilih secara random, kemudian sebelumnya diberi pretest untuk mengetahui keadaan awal antara kelompok eksperimen dan kelompok kontrol" (Sugiyono, 2012). Selanjutnya setelah diketahui hasil dari pretest dua kelompok tersebut, maka pada kelas eksperimen diberikan perlakuan (X), sedangkan pada kelas kontrol tidak diberikan perlakuan (X).

Tabel 1. Desain Penelitian Pretest-

Posttest Control Group Design

\begin{tabular}{llll}
\hline $\mathbf{R}$ & $\mathbf{0 1}$ & $\mathbf{X}$ & $\mathbf{0 2}$ \\
\hline $\mathrm{R}$ & 03 & & 04 \\
\hline
\end{tabular}

Keterangan :

$\mathrm{R}=$ kelompok dipilih secara random

$\mathrm{X}=$ perlakuan atau sesuatu yang diujikan

$\mathrm{O} 1=$ hasil pretest kelas eksperimen

$\mathrm{O} 3=$ hasil pretest kelas kontrol

$\mathrm{O} 2$ = hasil posttest kelas eksperimen

$\mathrm{O} 4$ = hasil posttest kelas kontrol

Sumber : (Sugiyono, 2012).

Populasi dalam penelitian ini adalah seluruh siswa kelas VII SMP Swasta Al-Ulum Medan. Sedangkan Sampel dalam penelitian ini adalah siswa kelas VII 3 sebagai kelas eksperimen yang mendapatkan pembelajaran dengan menggunakan pendekatan matematika realistik, dan siswa kelas VII 5 yang mendapatkan pembelajaran konvensional sebagai kelas kontrol.

Data dalam penelitian ini adalah data kuantitatif yang terdiri dari: 1) Data awal berupa skor yang diperoleh melalui pretest sebelum memulai pembelajaran. 2) Data akhir berupa skor yang diperoleh melalui posttest yang dilakukan di akhir pembelajaran atau setelah pemberian treatment, dan 3) Data pencapaian (gain).

Teknik pengumpulan data dalam penelitian ini terdiri dari empat teknik pengumpulan data, yaitu tes, observasi, dokumentasi, dan kepustakaan. Selanjutnya penelitian ini terdiri dari beberapa langkah penelitian yaitu: 1) Observasi awal untuk melihat kondisi lokasi atau tempat 
penelitian seperti: jumlah kelas, jumlah siswa, dan cara guru bidang studi mengajar. 2) Menentukan populasi dan sampel. 3) Menyusun dan menetapkan materi pelajaran yang akan digunakan dalam penelitian. 4) Menyusun Silabus dan Rencana Pelaksanaan Pembelajaran (RPP). 5) Membuat instrumen tes penelitian. 6) Melakukan validasi instrumen. 7) Mengujicobakan instrumen. 8) Melakukan perbaikan instrument tes. 9) Mengadakan tes awal (pretest) pada kedua kelas, kelas eksperimen dan kelas kontrol. 10) Melaksanakan kegiatan belajar mengajar pada kedua kelas. 11) Mengadakan tes akhir (posttest) pada kedua kelas. 12) Menganalisis data. 13) Membuat kesimpulan.

Dengan demikian, penelitian ini bertujuan untuk meningkatkan kemampuan berpikir kreatif siswa SMP Swasta Al-Ulum Medan kelas VII melalui pendekatan Matematika Realistik. Maka hipotesis untuk penelitian ini adalah peningkatan kemampuan berpikir kreatif matematis siswa yang memperoleh pembelajaran dengan pendekatan matematika realistik lebih baik daripada yang memperoleh pembelajaran konvensional.

\section{Hasil dan Pembahasan}

Secara deskriptif hasil penelitian yang berkenaan dengan peningkatan kemampuan berpikir kreatif siswa dengan pendekatan matematika realistik terlihat pada tabel 2

Tabel 2. Rata-rata Gain Ternormalisasi

Kemampuan berpikir kreatif Matematis Statistics

\begin{tabular}{|c|c|c|}
\hline & $\begin{array}{c}\mathrm{N}-\text {-Gain } \\
\text { Eksperimen }\end{array}$ & $\begin{array}{l}\text { N-Gain } \\
\text { Kontrol } \\
\end{array}$ \\
\hline Valid & 35 & 35 \\
\hline Missing & 0 & 0 \\
\hline Mean & 0,7877 & 0,5425 \\
\hline $\begin{array}{c}\text { Std. Error of } \\
\text { Mean }\end{array}$ & ,02784 & ,03789 \\
\hline
\end{tabular}

a. Multiple modes exist. The smallest value is shown

Sumber: hasil perhitungan SPSS 21,0 for Windows

Berdasarkan tabel 2, rerata gain ternormalisasi kelas eksperimen dan kelas kontrol berbeda, selisihnya 0,2452. Rerata gain ternormalisasi kelas eksperimen
$(0,7877)$ lebih tinggi dibandingkan kelas kontrol (0,5425), artinya peningkatan kemampuan berpikir kreatif matematis kelas eksperimen lebih baik daripada kelas kontrol.

Untuk menguji apakah peningkatannya signifikan atau tidak, maka dilakukan tahap kedua yaitu analisis statistik, langkah pertama yang dilakukan adalah uji prasyarat, yaitu uji normalitas dan homogenitas.

Pada uji normalitas gain ternormalisai kemampuan berpikir kreatif matematis, diperoleh hasil sebagai berikut.

Tabel 3. Hasil Uji Normalitas Data Gain

Ternormalisasi

Kemampuan Berpikir Kreatif Matematis Tests of Normality

\begin{tabular}{ll|r|r|r} 
& \multirow{2}{*}{ Kelas } & \multicolumn{3}{c}{ Kolmogorov-Smirnov ${ }^{\mathrm{a}}$} \\
\cline { 3 - 5 } & & \multicolumn{1}{c}{ Statistic } & \multicolumn{1}{c}{ df } & \multicolumn{1}{c}{ Sig. } \\
\hline N- & Eksperimen & 0,209 & 35 & $0,210^{*}$ \\
Gain & Kontrol & 0,162 & 35 & 0,077 \\
\hline
\end{tabular}

${ }^{*}$. This is a lower bound of the true significance. a. Lilliefors Significance Correction

Sumber: hasil perhitungan SPSS 21,0 for Windows

Nilai signifikansi kelas eksperimen dan kelas kontrol masing-masing 0,210 dan 0,77. Nilai signifikansi keduanya lebih besar dari 0,05 sehingga $\mathrm{H}_{0}$ diterima, artinya data gain ternormalisasi kelas eksperimen dan kelas kontrol berdistribusi normal. Selanjutnya hasil uji homogenitas terlihat pada tabel 4.

Tabel 4. Hasil Uji Homogenitas Data Gain

Ternormalisasi Kemampuan Berpikir Kreatif Matematis

Test of Homogeneity of Variances

\begin{tabular}{lccc}
\hline nilai Pretes & & & \\
\hline $\begin{array}{l}\text { Levene } \\
\text { Statisti } \\
\mathrm{c}\end{array}$ & $\mathrm{df1}$ & $\mathrm{df2}$ & Sig. \\
\hline 4.040 & 1 & 60 & .047 \\
\hline
\end{tabular}

Sumber: hasil perhitungan SPSS 21,0 for Windows

Karena nilai signifikasi yang diperoleh $0,047<0,05$ maka $\mathrm{H}_{0}$ ditolak, sehingga $\mathrm{H}_{1}$ diterima, maka data gain ternormalisasi kedua kelas tersebut tidak homogen. Karena data tersebut normal tetapi tidak homogen, maka langkah selanjutnya yang dilakukan adalah menguji 
hipotesis komparatif mengenai peningkatan kemampuan berpikir kreatif matematis siswa pada kelas eksperimen dan kontrol menggunakan uji t'.

Hipotesis adalah Peningkatan kemampuan berpikir kreatif matematis siswa yang memperoleh pembelajaran dengan pendekatan matematika realistik lebih baik daripada yang memperoleh pembelajaran konvensional. Dari Hasil Uji t' Data Gain Ternormalisasi Kemampuan Berpikir Kreatif Matematis terlihat bahwa nilai sig (2-tailed) pada Gain Equal Variances Not Assumed 0,000, sehingga nilai $\frac{\text { sig }(2-\text { tailed })}{2}=0,000<0,05$, maka $\mathrm{H}_{\mathrm{o}}$ ditolak, sehingga $\mathrm{H}_{1}$ diterima. Artinya rerata gain kemampuan berpikir kreatif matematis kelas eksperimen lebih tinggi daripada kelas kontrol. Sehingga dapat disimpulkan bahwa pada $\alpha=0,05$, peningkatan kemampuan berpikir kreatif matematis siswa yang memperoleh pembelajaran dengan pendekatan matematika realistik lebih baik daripada siswa yang memperoleh pembelajaran konvensional.

Siswono

(Saefudin,

2012)

mengungkapkan bahwa "Kemampuan berpikir kreatif siswa dapat dikembangkan dengan pendekatan matematika realistik karena adanya prinsip dan karakteristik pendekatan matematika realistik yang diterapkan dalam pembelajaran".

Hasil penelitian berupa analisis data kuantitatif di atas sejalan dengan hasil observasi pada kelas eksperimen yang menunjukkan ada peningkatan kemampuan berpikir kreatif siswa pada tiap pertemuan.

Sejalan dengan hasil analisis angket, hasil observasi menunjukkan sikap siswa merespon positif terhadap pembelajaran dengan pendekatan matematika realistik. Semangat siswa terlihat ketika dihadapkan dengan permasalaahan dunia nyata, karena mungkin selama ini pembelajaran yang selalu dihadapkan pada permasalahan secara konsep matematika dan abstrak. Sehingga dengan diterapkannya pembelajaran dengan pendekatan matematika realistik, siswa meresponnya dengan positif, dengan demikian dapat disimpulkan bahwa, sikap siswa terhadap pembelajaran dengan pendekatan matematika realistik adalah positif

\section{Simpulan}

Berdasarkan analisis hasil penelitian, maka penelitian ini dapat ditarik kesimpulan bahwa peningkatan kemampuan berpikir kreatif matematis siswa yang memperoleh pembelajaran dengan pendekatan matematika realistik lebih baik daripada siswa yang memperoleh pembelajaran konvensional, rerata gain normal untuk kelas eksperimen berada pada kategori tinggi, sedangkan untuk kelas kontrol berada pada kategori sedang.

\section{DaftarPustaka}

[1] Budiarto, F. d. (2013). Pengaruh Penggunaan Pendekatan OpenEnded terhadap Peningkatan Kemampuan Berpikir Kreatif Matematik pada Siswa SMP. Jurnal Pendidikan Matematika “SYMMETRY”. 2(2) , 294-303.

[2] Hariyati, H. I. (2013). Pengembangan Materi Luas Permukaan Dan Volum Limas Yang Sesuai Dengan Karakteristik Pmri Di Kelas Viii Smp Negeri 4 Palembang. Jurnal Pendidikan Matematika, 2(1) , 51-61.

[3] Mujib, A. (2018). Konflik Kognitif Dalam Pembelajaran Kalkulus II. Seminar Nasional Hasil Penelitian, (pp. 68-78.).

[4] Saefudin, A. (2012). Pengembangan Kemampuan Berpikir Kreatif Peserta didik dalam Pembelajaran Matematika dengan Pendekatan Pendidikan Matematika Realistik Indonesia (PMRI). Al-Bidāyah [Online] Vol 4 (1).

[5] Saragih, S. (2017). Developing Learning Model Based on Local Culture and Instrument for 
Mathematical Higher Order pertama di SMP Negeri 1 Sosopan tahun Thinking Ability International 2007 dan lulus pada tahun 2010. Setelah itu Education Studies. Canadian Center of Science, Vol. 10, No. 6.

[6] Siregar, R. N. (2019). Pengembangan Perangkat Pembelajaran Berbasis Pendekatan Realisitik Berbantuan ICT untuk Meningkatkan Kemampuan Berpikir Kreatif dan Self-Efficacy Siswa SMA Swasta Al-Ulum Medan. Medan: Universitas Muslim Nusantara Al-Washliyah.

[7] Sugiyono. (2012). Metode Penelitian Kuantitatif, kualitatif dan $R \& D$. Bandung: Alfabeta.

\section{Profil Penulis}

Penulis pertama yaitu Rama Nida Siregar, M.Pd. dilahirkan di Sosopan, pada tanggal 07 Juni 1995, anak ke delapan dari delapan bersaudara dari ayahanda Alm.Sahlan Siregar dan ibunda Fatimah Harahap. Pada tahun 2001, penulis menempuh Pendidikan Dasar di SD Negeri 0806 Medan Denai dan lulus pada tahun 2007. Melanjutkan sekolah menengah melanjutkan pendidikan di SMA Negeri 1 Batang Kuis tahun 2010 dan lulus pada tahun 2013. Pada tahun 2013, penulis melanjutkan pendidikan di Program Studi Pendidikan Matematika di Institut Agama Islam Negeri (IAIN) Padangsidimpuan dan lulus pada tahun 2017. Pada tahun 2017 penulis melanjutkan pendidikan di Program Pascasarjana Universitas Muslim Nusantara (UMN) Al Washliyah Medan Program Studi Magister Pendidikan Matematika.

Penulis kedua yaitu Dr. Abdul Mujib, M.PMat. merupakan dosen Universitas Muslim Nusantara (UMN) Al Washliyah Medan Program Studi Magister Pendidikan Matematika.

Penulis ketiga yaitu $\mathrm{Hj}$. Ida Karnasih, M.Sc. Ph.D. merupakan dosen Universitas Muslim Nusantara (UMN) Al Washliyah Medan Program Studi Magister Pendidikan Matematika.

Penulis keempat yaitu Prof. Dr. Hasratuddin, M.Pd. merupakan Profesor dibidang Matematika sekaligus dosen pascasarjana di Universitas Negeri Medan. 